\title{
Zaniklá středověká ves „Vsisko" z pohledu metod nedestruktivní prospekce
}

\section{Deserted medieval village "Vsisko" from the perspective of non-destructive survey methods}

\section{Michal Vágner / Tomáš Tencer / Michaela Prištáková / Jakub Šimík / Petr Dresler}

\begin{abstract}
Abstrakt
Studiem digitálních ortofotosnímků se podařilo na zaniklé vesnici „Vsisko” (k.ú. Dolní Bojanovice) rozpoznat jednak zbytky ohrazení v podobě př́kopu, jednak i několik plošných a bodových porostových příznaků, naznačujících př́tomnost sídlištních objektů uvnitř ohrazeného areálu. Ty se koncentrují okolo lineárního útvaru, interpretovaného jako pozůstatek cesty, která prochází středem vesnice. Severně od zaniklé vsi byl identifikován kruhový areál o průměru cca $25 \mathrm{~m}$, tvořený dvěma př́kopy, který byl interpretován jako pozůstatek drobného opevněného sídla. Na základě těchto zjištění byl na obou polohách proveden ve dvou etapách plošný geofyzikální průzkum, který odhalil ohrazení vesnice ze dvou směrů, částečně odhalil její vnitřní zástavbu a potvrdil fortifikaci v podobě dvojitého př́kopu nedalekého drobného opevněného sídla.
\end{abstract}

\section{Klíčová slova}

vrcholný středověk, zaniklá středověká vesnice, tvrz, ohrazené areály, dálkový průzkum Země, letecká prospekce, geofyzikální prospekce, nedestruktivní archeologie

\begin{abstract}
Within the study of digital orthophotos, we succeeded in identifying remains of an outer ditch in the deserted medieval village "Vsisko" (c.d. Dolní Bojanovice), as well as smaller and larger crop marks indicating the presence of a settlement inside the enclosed area. These potential archaeological components concentrate around a linear feature that passes through the center of the village, which could be interpreted as a possible remnant of the historical path. A circular area, formed by two ditches, about $25 \mathrm{~m}$ in diameter was identified North of the deserted village and interpreted as a remnant of a small moated site. Based on these findings, a two-phase geophysical survey was carried out on both locations, revealing the fortification of the village from two directions. In addition, the survey partly revealed the village's ground plan, confirming the fortification in the form of a double ditch of the nearby moated site.
\end{abstract}

\section{Keywords}

high Middle Ages, deserted medieval village, moated site, enclosed areas, remote sensing, aerial photography, geophysical survey, nondestructive archaeology 


\section{1. Úvod}

Vrcholně středověká, popřípadě raně novověká vesnická sídla stála v oblasti Dolnomoravského úvalu až do nedávné doby mimo hlavní pozornost většiny archeologů. Ta byla v minulosti z velké části věnována studiu raně středověkého osídlení a lokality z tohoto období byly zkoumány povětšinou namátkově, formou povrchových sběrů, anebo v rámci záchranných archeologických výzkumů. V 70. a 80. letech minulého století patřil mezi výjimky J. Unger, který se zaměřil na systematický výzkum zaniklých středověkých vesnic na Pohořelicku (např. Unger 1974; 1975; 1982) a brněnském Kloboucku (Unger 1987; 1988). Zde se zabýval stejným tématem i E. Kordiovský (např. Kordiovský 1977; 1980). Na počátku 90. let se díky letecké prospekci podařilo odhalit několik zaniklých vesnic, které byly obehnány příkopem (Bálek 1997, 307, 311; Bálek - Unger 1996; 1996a). V nedávné době se podařilo díky studiu nejnovějších družicových a leteckých ortofotosnímků identifikovat stejný typ ohrazení u dalších zaniklých vesnic a významně tak rozšíríit počet těchto lokalit v dané oblasti (Vágner - Škurňák - Dresler 2018). Na některých z nich byl proveden nedestruktivní archeologický výzkum v podobě geofyzikální prospekce (Dresler-Tencer-Vágner 2015a; 2015b). Mezi tyto lokality se řadí i ZSV „Vsisko“. V roce 2013 zde byla v místech kruhového útvaru, tvořeného dvěma tmavými pásy porostových příznaků, zjištěnými v rámci dálkového průzkumu Země, provedena nedestruktivní magnetometrická prospekce. Ta potvrdila přítomnost předpokládaného drobného opevněného sídla na lokalitě (Dresler - Tencer 2016). To nebylo v minulosti zcela neznámé. Podle V. Oharka (dubňanského faráře v letech 1875-1895), který označil toto místo termínem „Zámčisko“, byl pahorek se zbytky valu a příkopem stále viditelný ještě v 70. letech 19. století. V roce 2016 byl na loka- litě proveden opětovný geofyzikální průzkum za pomoci magnetometrie, který se tentokrát zaměřil na samotnou plochu zaniklé vsi.

\section{Popis lokality, její historie a identifikace}

Zaniklá středověká ves „Vsisko“ se nachází ve stejnojmenné trati, v místech mezi asfaltovou cestu vedoucí od Bojanovic ke státní silnici Hodonín - Brno a lesem zvaným „Dolní Kapansko“, asi dva kilometry severovýchodně od středu obce Dolní Bojanovice. Lokalita je situována na svazích mírného údolí, které se táhne od jihu k severu v rozmezí nadmořských výšek 179 až $183 \mathrm{~m} \mathrm{n}$. m. To navazuje na údolí vycházející z výše zmíněného lesa, které pokračuje dále východním směrem, kde se napojuje na údolí Stupavy / Kyjovky. Severně od zaniklé vesnice se nachází polní tratě „Díly nad Vyšickem“ a „Díly nad Zámčiskem“, východně trał "Malé Písky“, jižně pak polní trat' „Nivky“. Podle listů povinného císařského otisku stabilního katastru z roku 1827 a II. vojenského mapování z roku 1841 byl prostor vesnice v první polovině 19. století zatravněn. Dnes se zde nachází intenzivně zemědělsky obdělávané pole. V těsné blízkosti lokality, na její východní straně, se nalézá vrt na zemní plyn. Lokalita se nachází na spraších s černozemním půdním typem (Obr. 1, 2, 3).

Název „Vsisko“ pochází z lidové tradice. Původní název lokality neznáme a ani není znám rok, kdy byla vesnice založena. V historických pramenech je vesnice poprvé zmiňována již jako pustá v urbáři panství hodonínského z roku 1691, kde je poznamenáno: „Dědina Vsisko jsouc od množství let pustá a nejsouc naděje k osazení pro ouzkost živností a pasunkův, byla rozdělena mezi sousední vsi.“ Pozemků užívali poddaní a platili desátou kopu jak z jařin, tak i z ozimů (Nekuda 1961, 146). Podle V. Nekudy 

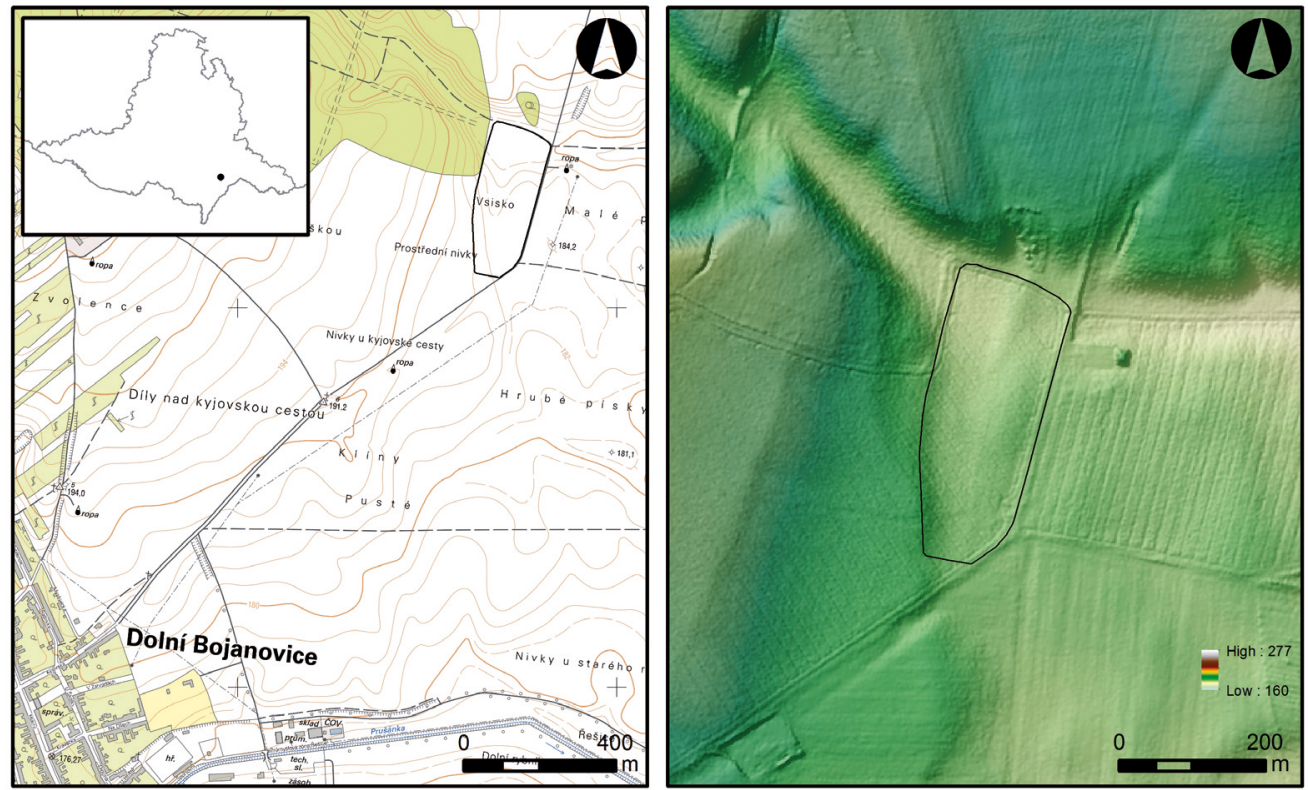

Obr. 1. Vlevo: Lokalizace ZSV „Vsisko” na výřezu mapy ZM 10. Vpravo: ZSV „Vsisko” na výškopisném modelu (autor: Michal Vágner).

Fig. 1. Left: Localisation of DMV "Vsisko" in a cut-out from a map ZM 10. Right: DMV "Vsisko" in an altimetric model (author: Michal Vágner).
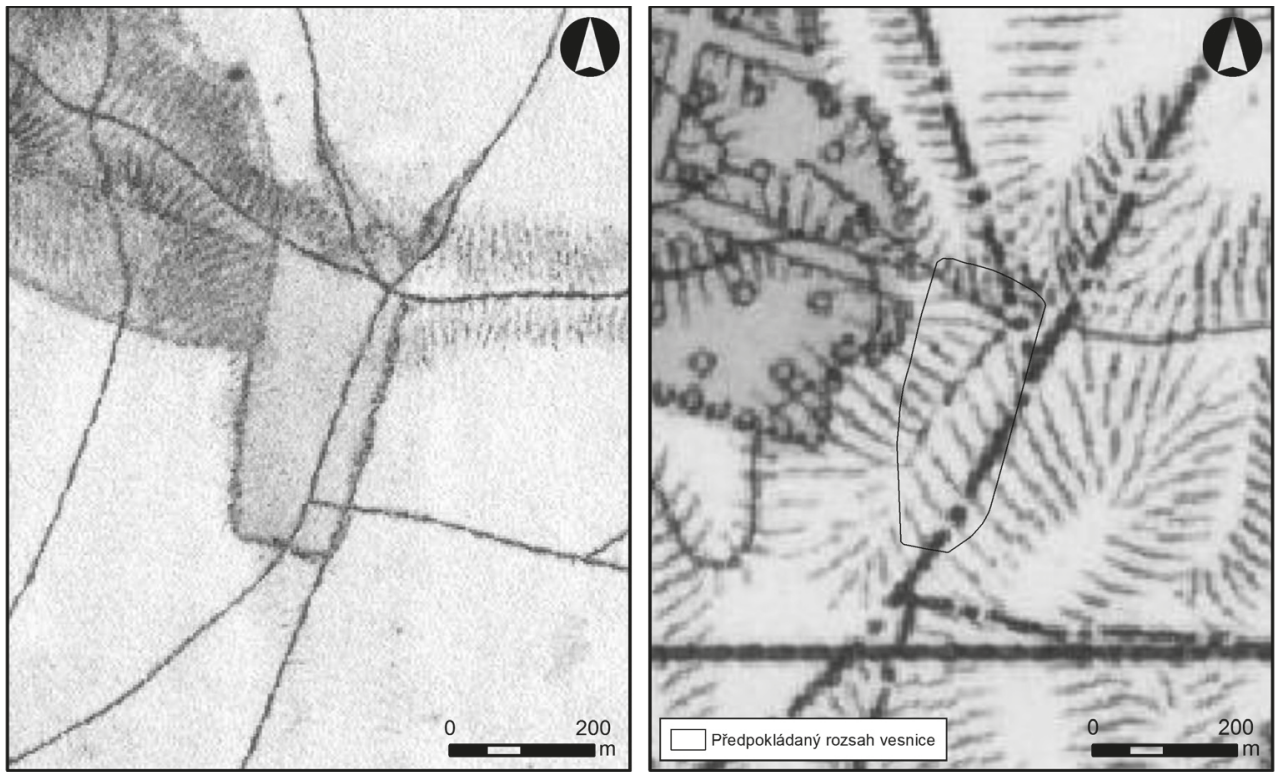

Obr. 2. Vlevo: ZSV „Vsisko” na II. vojenském mapování z roku 1841. Vpravo: Lokalita na III. vojenském mapování z let 1876-1878 (zdroj: ČÚZK; autor: Michal Vágner).

Fig. 2. Left: DMV "Vsisko" in the Second Military Survey from 1841. Right: Locality in the Third Military Survey from 1876-1878 (source: Czech Office for Surveying, Mapping and Cadastre; author: Michal Vágner). 

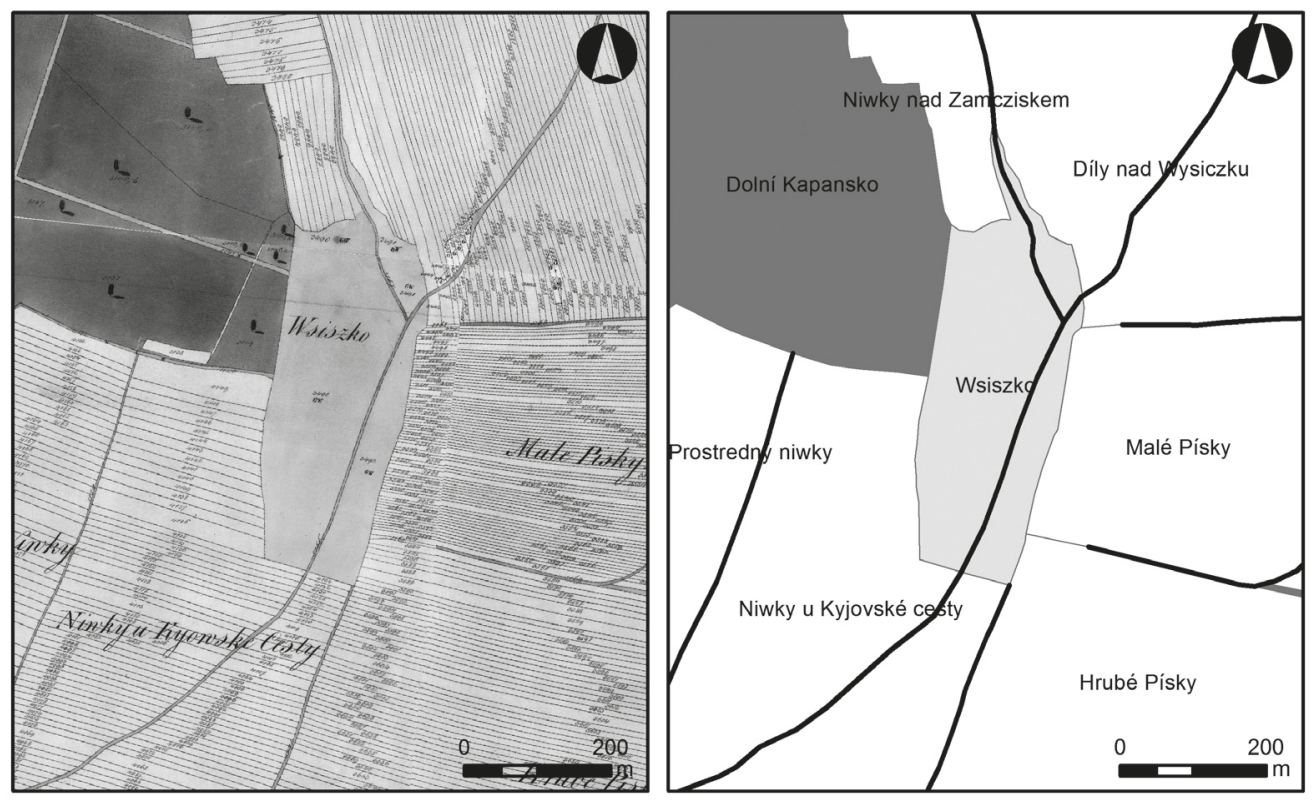

Obr. 3. Vlevo: ZSV "Vsisko" na povinných císařských otiscích stabilního katastru z roku 1827. Vpravo: Polní tratě v prostoru ZSV "Vsisko". Převzato a upraveno z listů stabilního katastru (zdroj: ČúZK; autor: Michal Vágner).

Fig. 3. Left: DMV "Vsisko" in Imperial Obligatory Imprints of the Stable Cadastre from 1827. Right: Field plots in the area of DMV "Vsisko". Borrowed and edited from Stable Cadastre sheets (source: Czech Office for Surveying, Mapping and Cadastre; author: Michal Vágner).

se jednalo o ves „Kreutz“, ale tato domněnka byla L. Janem vyvrácena a název byl přiřazen nedalekým Mutěnicím (Jan - Štěpánek 2002).

\section{Vsisko z ptačí perspektivy}

Poměrně velké množství informací o lokalitě lze získat studiem snímků pořízených v rámci dálkového průzkumu Země (zkr. DPZ). Již na nejstarších leteckých snímcích, pořízených na konci let 40. a na počátku let 50. a 60., je dobře patrné ohrazení zaniklé vsi, které se projevuje v podobě několika metrů širokého pásu s mírně vzrostlou křovinatou vegetací. Tento remízek je zachycený jak na snímcích z let 1938, 1953 a 1963, tak i na starších historických mapových archiváliích (Obr. 2, 3,4). Táhne se po západní straně zaniklé vsi směrem na sever, kde se vytrácí s hranicí lesa. Na jihu vytváří nároží, které se stáčí směrem na východ. Zde mizí pod asfaltovou cestou, která ohraničuje areál z východní strany. Na leteckém snímku z roku 1938 je dobře vidět, že remízek odděluje dva na sobě nezávislé systémy polních parcel - uvnitř a vně ohrazeného areálu. Podle snímku z roku 1953 se ovšem zdá, že menší pole uvnitř ohrazeného areálu už byla zcelena, kdežto pole v okolí zaniklé vesnice jsou stále rozdělena na menší parcely. Jinak je tomu již na snímku z roku 1963, kde jsou i okolní pole sjednocena do větších lánů. Stále je však na leteckém snímku patrné ohraničení zaniklé vsi z její západní a jihozápadní strany. Někdy po tomto roce muselo dojít k jeho rozorání a ke sjednocení polí vně a uvnitř areálu zaniklé vesnice. Na novějších ortofotosnímcích jsou pozůstatky ohraničení patrné na snímcích z roku 2009, kde se projevují asi 

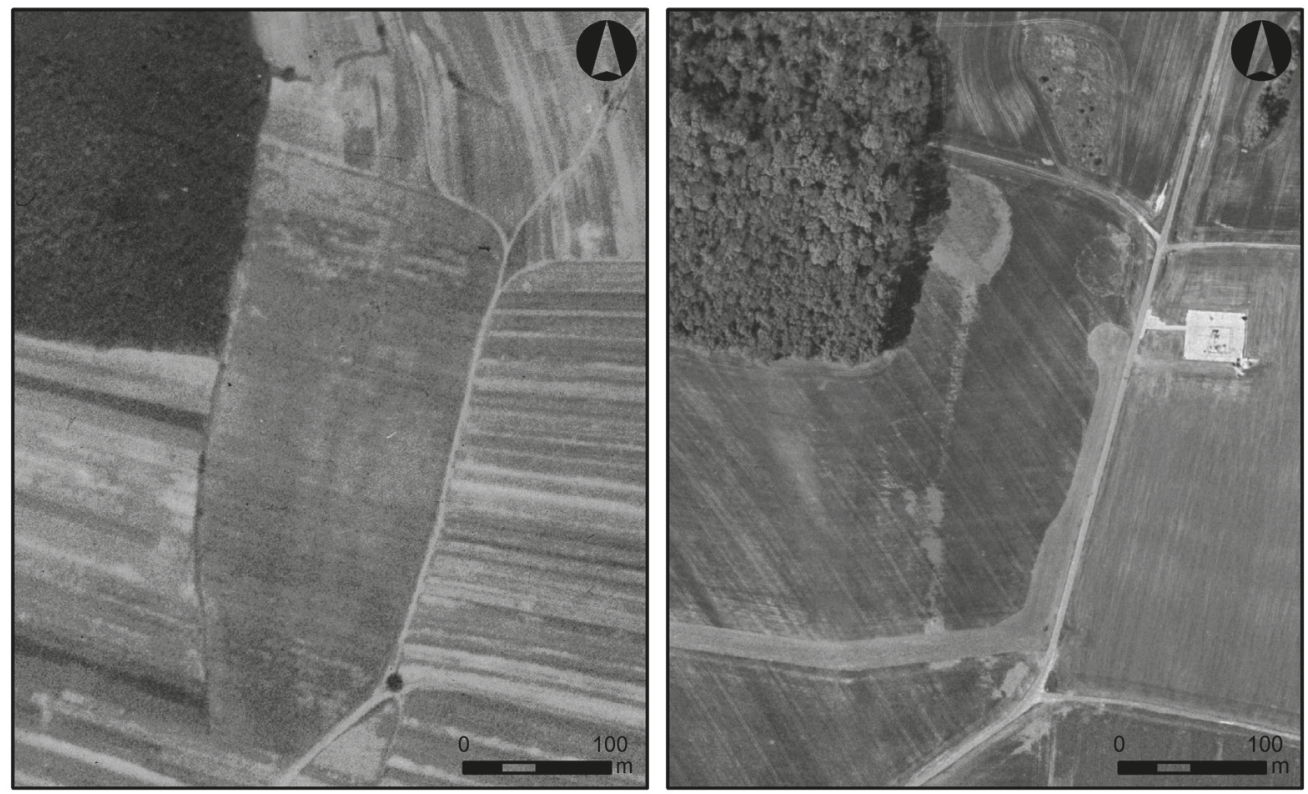

Obr. 4. Vlevo: ZSV "Vsisko" na ortofotosnímku z roku 1953 (zdroj: agentura CENIA/GEODIS Brno). Vpravo: ZSV „Vsisko" na ortofotosnímku z roku 2006 (zdroj: ČÚZK; autor: Michal Vágner).

Fig. 4. Left: DMV "Vsisko" in an orthophoto from 1953 (source: CENIA/GEODIS agency Brno). Right: DMV "Vsisko" in an orthophoto from 2006 (source: Czech Office for Surveying, Mapping and Cadastre; author: Michal Vágner).

3 až $4 \mathrm{~m}$ širokým tmavým pásem porostových příznaků.

Severní ohraničení zaniklé vsi je sporné. Podle snímku od Českého úřadu zeměměřického a katastrálního z roku 2009 v kombinaci se snímkem společnosti GEODIS z téhož roku (dostupný na GoogleEarth) lze pozorovat v severní části areálu příčný pruh probíhající ve směru východzápad (Obr. 5). Přri geofyzikálním průzkumu se zde však žádné zbytky ohrazení nepodařilo zachytit. $\mathrm{V}$ tomto případě lze uvažovat nad dvěma pravděpodobnými variantami. Bud' toto severní ohrazení kopíruje průběh dnešní polní cesty vedoucí z lesa „Dolní Kapansko“ směrem k asfaltové komunikaci, podobně jak tomu může být na východní straně lokality, anebo se toto ohrazení nachází necelých 100 metrů severně od polní cesty, a to v těsné blízkosti severního okraje drobného opevněného sídla zjištěného geofyzi- kální prospekcí v roce 2013. Tomuto může napovídat stav zachycený na II. vojenském mapování a císařských otiscích stabilního katastru, kde je dobře patrná hranice mezi pravděpodobným vnitřním areálem zaniklé vsi (v té době patrně sloužícím jako pastviny) a okolními polnostmi (Obr. 2, 3). Na listu toposekce třetího vojenského mapování z roku 1936 je západní strana vesnice vymezena dva metry vysokou mezí. Zbytky této hranice jsou ještě patrné i na leteckých snímcích z let 1938, 1953 a 1963.

Na základě těchto informací lze tedy soudit, že vesnice mohla být v průběhu svého trvání nejméně ze dvou stran ohrazena. Jako nejpravděpodobnější forma ohrazení se jeví 3 až $4 \mathrm{~m}$ široký příkop, jehož analogie známe i z jiných zaniklých vesnic - naprŕíklad z nedalekých Opatovic (k.ú. Hrušky u Břeclavi) či Potvorovic (k.ú. Nový Poddvorov). 

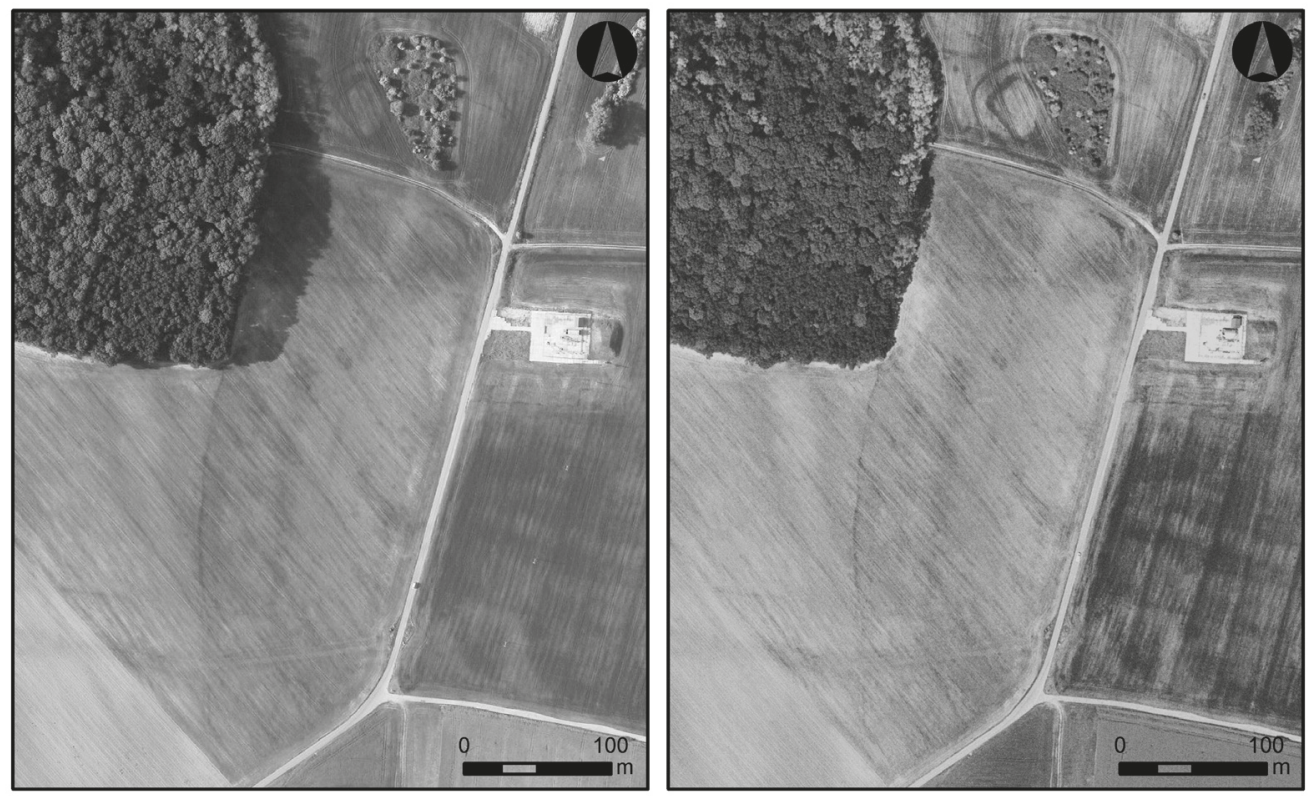

Obr. 5. ZSV „Vsisko” na ortofotosnímcích z roku 2009 (vlevo zdroj: GEODIS Brno; vpravo zdroj: ČúZK; autor: Michal Vágner).

Fig. 5. DMV "Vsisko" in orthophotos from 2009 (source left: GEODIS Brno; source right: Czech Office for Surveying, Mapping and Cadastre; author: Michal Vágner).

Podle ortofotosnímků je patrné, že středem vesnice prochází několik linií. Jižní a východní část ohrazeného areálu vesnice je narušena průběhem několika inženýrských sítí. Jedná se o plynovody, které jdou od vrtu na východní straně lokality k zásobníku na zemní plyn stojícího několik kilometrů západně. Daleko zajímavěji se jeví dva tmavé pásy, které se táhnou středem areálu od severu na jih. Západnější, excentricky posazený, je zřejmě dnem mírně rozevřeného nízkého údolí, ve kterém se vesnice nacházela. Že jde o občasnou svodnici, dokládá ortofotosnímek z roku 2003 (Obr. 4). Na něm je zřejmé, že po jarních deštích je splachována půda severním směrem, kde sedimenty vytvářejí kruhovitý útvar. Východně položený lineární útvar lze interpretovat opět jako zaniklou vodoteč, anebo spíše jako pozůstatek po zaniklé středové komunikaci, která procházela v severojižní ose vesnice. Tomu by nasvědčoval i fakt, že se okolo domnělé cesty koncentrují porostové příznaky v podobě několika větších i menších tmavších plošných i bodových útvarů, které lze interpretovat jako možné pozůstatky sídlištních objektů.

Jak už bylo zmíněno v úvodní kapitole, v poloze označované jako „Zámčisko“, která se nachází asi $120 \mathrm{~m}$ severně od zaniklé vsi, je na ortofotosnímcích patrný kruhový areál o průměru cca $25 \mathrm{~m}$, který je tvořen dvěma příkopy o šířce cca 3 až $6 \mathrm{~m}$. Na východní straně je průběh př́kopů narušen bývalou pískovnou, na jižní straně polní cestou. Jedná se o pozůstatek drobného opevněného sídla, které bylo v roce 2013 potvrzeno geofyzikální prospekcí. F. Esterka tuto lokalitu i s vesnicí v minulosti ztotožňoval nejprve s nedalekou zaniklou vsí zvanou „Kapansko“ či „Kapanice“, která se nachází po levé straně silnice z Mutěnic do Čejkovic na rozmezí tratí „Hrubé Padělky“ a „Nové Kapánsko“. 


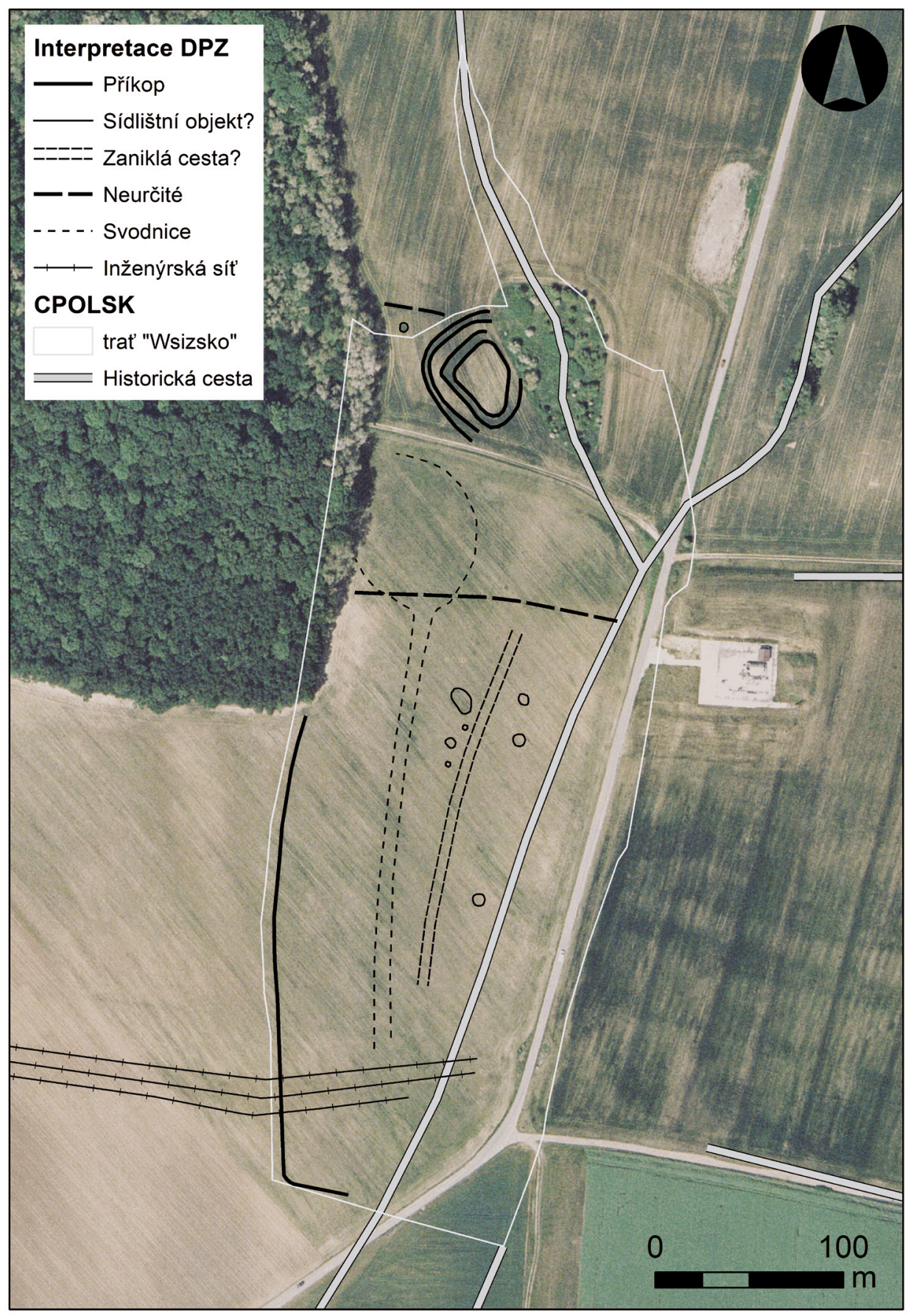

Obr. 6. Interpretované porostové příznaky na ZSV „Vsisko” (podkladové foto - zdroj: ČúZK; autor: Michal Vágner). Fig. 6. Interpreted crop marks in the DMV "Vsisko" (background photo - source: Czech Office for Surveying, Mapping and Cadastre; author: Michal Vágner). 
Posléze spojoval „Vsisko“ i s opevněným sídlem s další zaniklou vsí „Kuničky“, která se měla podle dostupných informací nacházet někde mezi Dolními Bojanovicemi a Hodonínem (Esterka - Ondruš 1996, 22). Podle V. Nekudy stávaly „Kuničky“ snad u Zbrodské myslivny a po roce 1497, kdy byly zapsány jako pusté, byl v jejich místech zrrízen rybník (Nekuda 1961, 61-62). Musíme však přijmout zápis z roku 1691 o tom, že dědina „Vsisko“ je již mnoho let pustá. Z těchto důvodů tak prozatím nemůžeme žádnou ze zaniklých vsí, u kterých je zmiňována tvrz, sjednotit s relikty prozkoumanými prospekcí a studiem ortofotosnímků (Dresler Tencer 2016, 29).

\section{Geofyzikální průzkum}

K průzkumu sídlištních areálů mimo moderní zástavbu se z geofyzikálních metod nejlépe osvědčila magnetometrie. Tato nedestruktivní metoda umožňuje efektivní a rychlou detekci a identifikaci sídlištních a jiných struktur na rozsáhlých plochách (Dresler - Tencer - Vágner 2015a; Milo 2009; 2013; 2014). Podstatou metody je měření intenzity magnetického pole Země. $\mathrm{V}$ rámci tohoto pole jsou registrovány lokální anomálie, jejichž vznik je spojován s přítomností podpovrchových struktur nejčastěji geologického, pedologického, anebo antropogenního původu. Do poslední jmenované kategorie se řadí i archeologické objekty.

Základním předpokladem k úspěšné identifikaci těchto struktur je jejich dostatečný kontrast vůči podloží - respektive vůči jejich bezprostřednímu okolí. Nejdůležitější ovšem nejsou absolutní hodnoty magnetického pole, ale právě rozdíl mezi zásypy objektů a jejich okolí. Kromě výrazné výplně a tvaru objektu je při archeologické interpretaci geofyzikálních dat velice důležitým faktorem samotný rozsah prozkoumané plochy. Jenom dostatečně plošně rozsáhlý průzkum může zodpovědět otázky související s rozsahem osídlení a jeho intenzitou nebo s charakterem antropogenní činnosti na zkoumaném místě (Křivánek 2004, kap. 4.4).

Při magnetometrickém průzkumu jsou anomálie s kladnou hodnotou změny intenzity magnetického pole obvykle interpretovány jako zahloubené archeologické objekty - jámy apod. Anomálie s negativní změnou intenzity magnetického pole lze pak nejčastěji interpretovat jako zahloubené objekty obsahující kamenný zásyp, anebo jako kamenné struktury - například pozůstatky zdiv apod. Třetím typem jsou tzv. bipolární anomálie, které jsou charakteristické výraznou kladnou i zápornou složkou. Ty nejčastěji indikují přítomnost ferromagnetických materiálů - např́klad kusů železa, anebo přepálených struktur - pecí, ohništ atd.

V návaznosti na prospekci opevněného sídla, která byla provedena v roce 2013 , jsme se v druhé etapě zaměřili na samotný intravilán zaniklé vsi „Vsisko“. Během jednoho dne se podařilo prozkoumat plochu o celkové rozloze 6,718 ha. $\mathrm{K}$ prospekci byl použit fluxgate magnetometr LEA MAX (Eastern Atlas, Německo) s deseti sondami FEREX CON 650. Magnetometr je konstruován jako gradiometr, který zaznamenává rozdíly vertikálních prvků magnetického pole ve dvou odlišných výškách od povrchu. Horizontální vzdálenost mezi jednotlivými sondami byla stanovena na $0,5 \mathrm{~m}$, vertikální vzdálenost mezi dvěma senzory v každé sondě byla fixních 0,65 m. Přístroj umožňuje kontinuální měření hodnoty změny intenzity magnetického pole $\mathrm{s}$ přesností $0,2 \mathrm{nT} / \mathrm{m}$, a to ve frekvenci několik desítek měření za sekundu. Měření bylo provedeno v manuálním módě v síti $0,25 \times 0,50 \mathrm{~m}$, a to $\mathrm{v}$ předem vytyčených polygonech. Rohy jednotlivých polygonů byly vytyčeny s pomocí geodetického RTK GNSS př́stroje Leica Viva GS15 s přesností okolo jednoho centimetru za ideálních podmínek. 
Data z měření byla spravována standardním postupem v programu LEAD2. Mapa změny magnetické intenzity magnetického pole (magnetogram) v nanotesla (nT) byla následně vyhlazena průměrovacím filtrem. Pro účely prezentace a interpretace výsledků byl použit software ArcGIS Desktop 10.3 (ESRI).

\section{Interpretace dat}

Cílem geofyzikální prospekce na ZSV „Vsisko“ bylo jednak potvrzení průběhu předpokládaného ohrazení vesnice a jednak identifikace potenciálních archeologických objektů a jiných struktur uvnitř ohrazeného areálu.

Na lokalitě bylo magnetometrickým průzkumem zjištěno velké množství anomálií, které lze dát do souvislosti s antropogenní činností. Anomálie můžeme na základě hodnot intenzity magnetického pole rozdělit na bipolární a na anomálie s převážně pozitivními či negativními hodnotami (Obr. 7, 8).

Výsledky prospekce byly bohužel z velké části ovlivněny recentními inženýrskými sítěmi, které se projevují jako výrazné bipolární lineární anomálie s vysokými hodnotami změn intenzity magnetického pole v řádech několika stovek nT. Tyto anomálie z vysokými hodnotami měly za následek to, že všechny další potencionální anomálie v jejich bezprostředním okolí byly odstíněny. Zachycené sítě se táhnou po východní straně lokality od vrtu na zemní plyn směrem k jihu, kde se stáčí směrem na západ a pokračují k asi 1 km vzdálenému zásobníku na plyn. Další sít, jejíž část byla zachycena již při průzku$\mathrm{mu} \mathrm{v}$ roce 2013, vede diagonálně přes lokalitu ve směru SZ-JZ.

Ostatní identifikované bipolární anomálie můžeme na základě jejich velikosti rozdělit na malé a velké. Menší bipolární anomálie (velikostí do cca $0,5 \mathrm{~m}$ ), jejichž změny v magnetických hodnotách se pohybují v řádech stovek nT, jsou často interpretovány jako drobné magnetické předměty ležící na samém povrchu, anebo v ornici těsně pod ním. Nejčastěji jde o drobné kovové zlomky většinou recentního stáří, anebo o úlomky magnetických hornin (Hladik - Milo - Tencer - Zeman 2013). Vzhledem k tomu, že v širším okolí lokality není výskyt magnetických hornin častý, lze menší bipolární anomálie interpretovat jako různorodé kovové artefakty, které nejpravděpodobněji souvisí s dlouhodobou zemědělskou činností na lokalitě.

Větší bipolární anomálie (v řádech metrů) jsou pravděpodobně výsledkem termoremanentního magnetismu. Na lokalitě jich bylo identifikováno celkem 7. Hodnota změny intenzity magnetického pole se u zaznamenaných anomálií pohybuje od -10 nT do +38 nT. Jedná se o objekty s výraznou složkou přepáleného materiálu, které můžeme interpretovat jako možná potravinářská, otopná anebo výrobní pyrotechnická zařízení.

Vyjma bipolárních anomálií bylo na lokalitě zachyceno velké množství anomálií s pozitivními hodnotami, které lze dát do souvislosti se zaniklou vesnicí. Na západní a jižní straně zkoumané plochy je zřetelně vidět lineární anomálie, kterou lze na základě předešlých informací interpretovat jako relikt příkopu. Ten svým průběhem koreluje jak s historickými mapovými archiváliemi, tak i s porostovými př́znaky identifikovanými za pomoci dálkového průzkumu Země. Na magnetogramu je velice dobře zřetelné jeho jihozápadní nároží, kde se příkop stáčí směrem k východu. Jeho průběh lze vysledovat až $\mathrm{k}$ asfaltové cestě. Asi $50 \mathrm{~m}$ východně od cesty by se měl příkop podle historických mapových archiválií stáčet opět k severu. Bud' přímo kopíruje průběh asfaltové komunikace, která. ho po celé jeho východní délce překryla, anebo se nachází východně v její těsně blízkosti. Vlivem nepříznivých podmínek bohužel nebylo možné ani na jednom z těchto míst prospekci provést a tyto domněnky zůstávají prozatím 


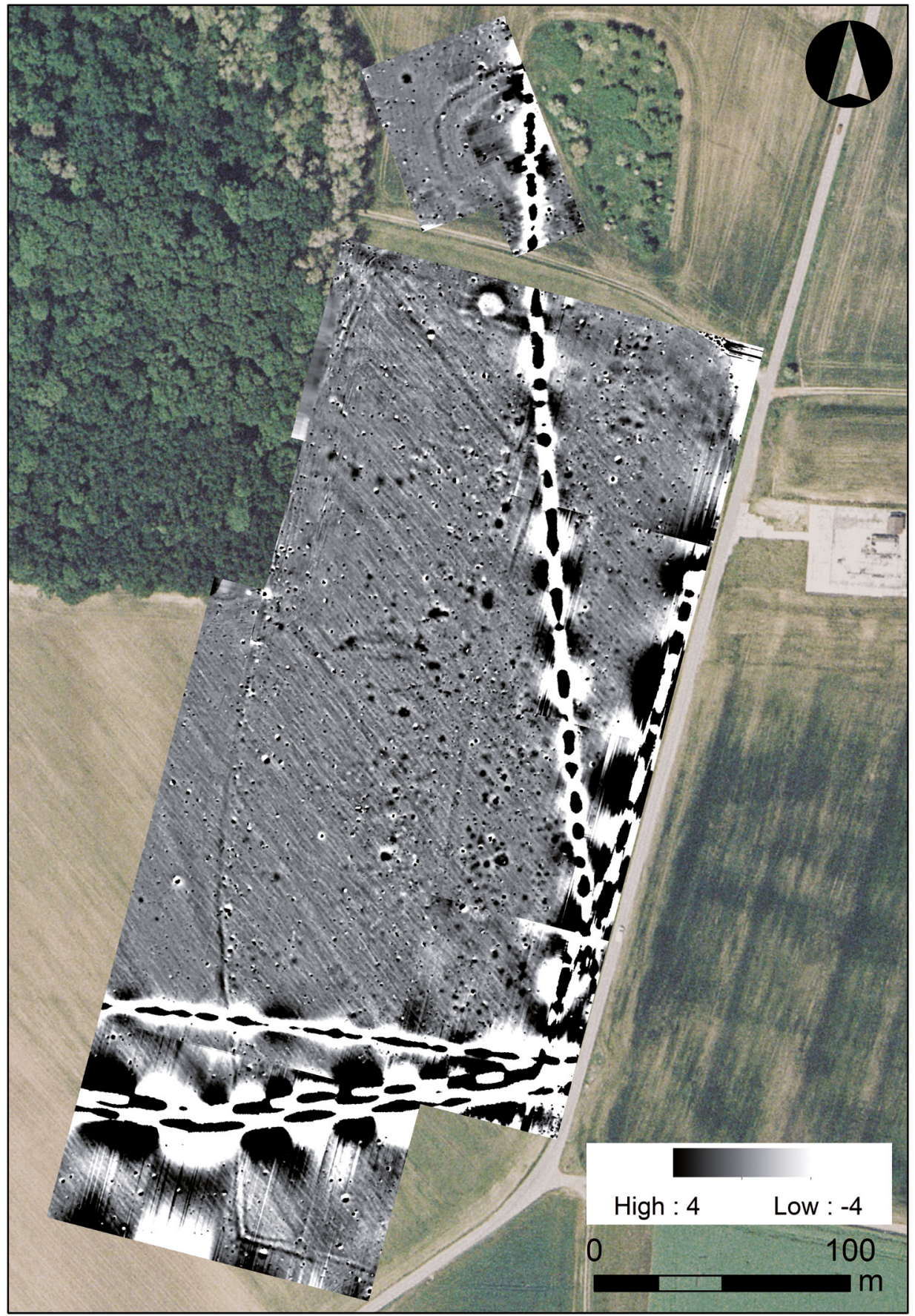

Obr. 7. Výsledky geofyzikální prospekce - magnetogram (podkladové foto - zdroj: ČúZK; autor: Michal Vágner). Fig. 7. The outcomes of geophysical survey - magnetogram (background photo - source: Czech Office for Surveying, Mapping and Cadastre; author: Michal Vágner). 
nepotvrzeny. Díky geofyzikální prospekci se podařilo nově odhalit, že př́kop je v jižní části zdvojený a jeho průběh je zhruba uprostřed přerušen. $\mathrm{V}$ př́ípadě severněji položeného př́íkopu jde o cca $10 \mathrm{~m}$ širokou mezeru, u jižněji situovaného příkopu je šířka přerušení cca $4 \mathrm{~m}$. Otázka je, zda je tato proluka zapř́íčiněna špatnou čitelností dat vlivem silného magnetismu nedalekého recentního plynovodu, anebo se opravdu jedná o vstup do ohrazeného areálu. Tomu by nasvědčovala i přítomnost další pozitivní lineární anomálie, která prochází středem vesnice v severojižním směru, paralelně s její delší osou, a jejíž průběh lze odhadnout směrem k domnělému vstupu do ohrazeného areálu. Zachycena byla na dvou místech, a to v délce 25 a 50 m. Je možné, že se jedná o starší fázi historické cesty, jejíž průběh je zachycen na historických mapových archiváliích, a která v době existence vesnice vedla jako severojižní osa vesnice. Této skutečnosti by napovídal i další fakt, a to rozmístění dalších anomálií s pozitivními hodnotami magnetické indukce. Ty lze totiž interpretovat jako pravděpodobné pozůstatky zahloubených objektů sídlištního charakteru. Nacházejí se po obou stranách cesty, v její těsné blízkosti a respektují její průběh v celé její zachycené délce. Ve větší míře se koncentrují na východ od ní, kde tvoří jakési shluky objektů. Mezi nimi se nachází i výše popsané bipolární anomálie interpretované jako přepálené objekty - možné relikty pyrotechnických zařízení. Bohužel je tato strana silně narušena recentním plynovodem, který z velké části odstínil další potencionální anomálie. I přesto, že zde nebyly jednoznačně identifikovány doklady obytných staveb, lze se na základě distribuce sídlištních objektů domnívat, že větší část sídelních aktivit se odehrávala na východní straně od cesty. Na západní straně od cesty jsou sídlištní objekty zastoupeny v menší míře a mají odlišné prostorové uspořádání. Nicméně, díky několika bipolárním anomáliím, které se na této straně podařilo zachytit a které mohou indikovat přítomnost pyrotechnických zařízení, a díky prrítomnosti několika kumulací větších i menších pozitivních anomálií, interpretovaných jako sídlištní objekty, lze předpokládat, že se i na této straně nacházely objekty obytného charakteru.

V severozápadní části zkoumané plochy byla zachycena menší lineární anomálie, která se táhne s hranicí lesa severovýchodním směrem. Pravděpodobně se jedná o zbytek příkopu. Nelze vyloučit, že se táhne až k drobnému opevněnému sídlu a společně s jeho vnějším příkopem tvoří vnější ohrazení celého areálu vesnice sídlo. Vnitřní obdélný příkop by pak vymezoval jen samotné opevněné sídlo. Vzhledem k tomu, že se vnější příkop opevněného sídla v jihozápadním rohu stáčí směrem dovnitř̆, kde po pár metrech končí, tak je možné, že se v těchto místech mohl nacházet i vstupní koridor do celého komplexu vedoucí ve směru SZ - JV.

V západní části ohrazeného areálu se v rámci dálkového průzkumu Země podařilo identifikovat občasnou svodnici, která v severní části lokality vytváří kruhový útvar ze splachových sedimentů. Ty pravděpodobně ovlivnily i výsledky magnetometrické prospekce v těchto místech. Vlivem jednak erozní, jednak sedimentární činnosti, se v průběhu svodnice a ani v místech kruhového útvaru nepodařily zachytit žádné výraznější anomálie s pozitivními ani negativními hodnotami magnetické indukce. Průzkumem byly zachyceny pouze menší bipolární anomálie, které ale pravděpodobně souvisí s recentní zemědělskou činností na lokalitě. Je otázkou, zda se v těchto místech opravdu nic nenachází, anebo byly veškeré doklady lidské činnosti související se zaniklou vesnicí překryty splachovými sedimenty a nebylo je tak možné identifikovat stávající geofyzikální prospekcí.

Na lokalitě byl dále zachycen výrazný, opakující se vzor linií v SZ-JV směru, který částečně komplikoval identifikaci dalších lineárních 


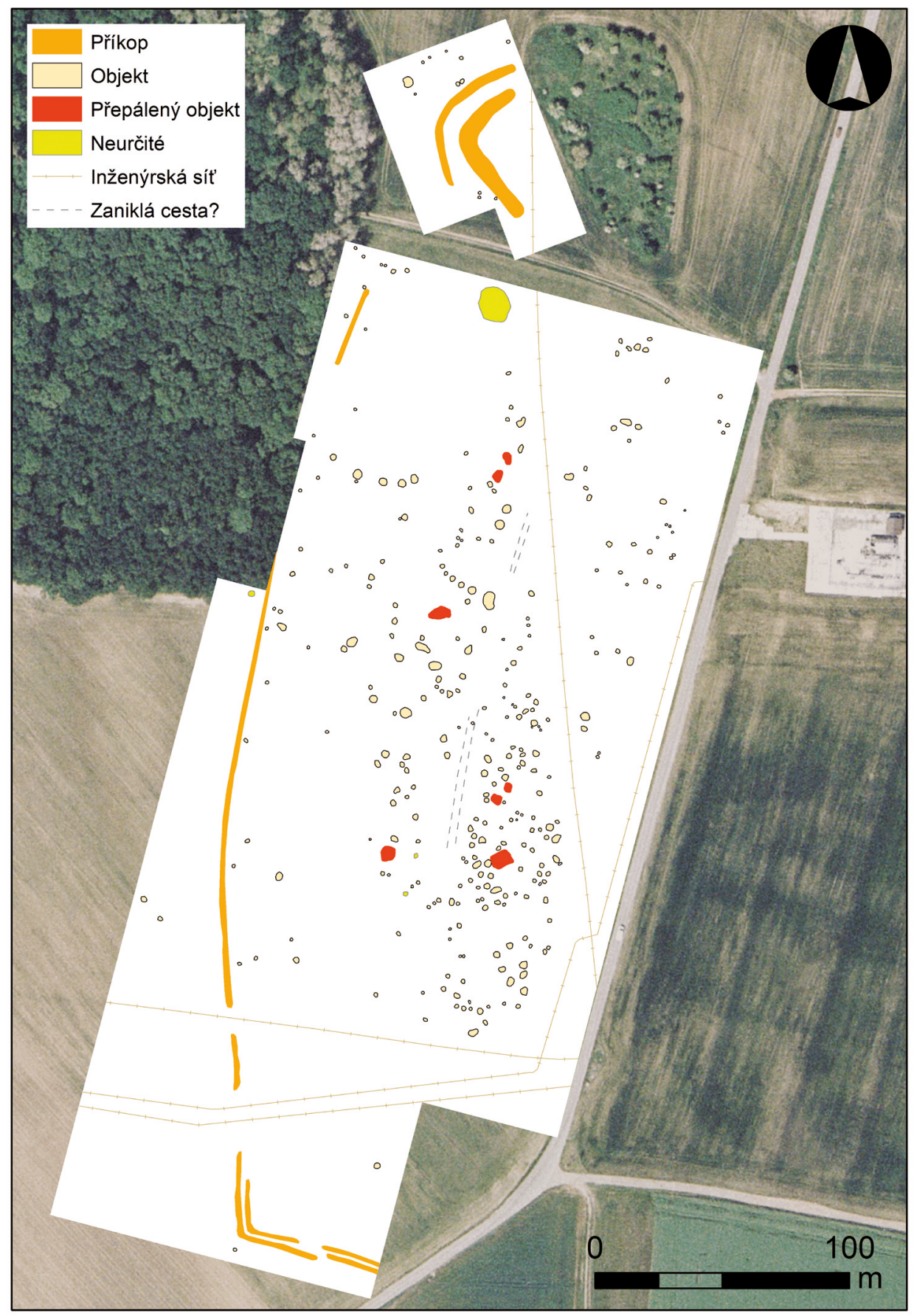

Obr. 8. Výsledky geofyzikální prospekce - interpretační plán (podkladové foto - zdroj: ČÚZK; autor: Michal Vágner). Fig. 8. The outcomes of geophysical survey - interpretation plan (background photo - source: Czech Office for Surveying, Mapping and Cadastre; author: Michal Vágner). 


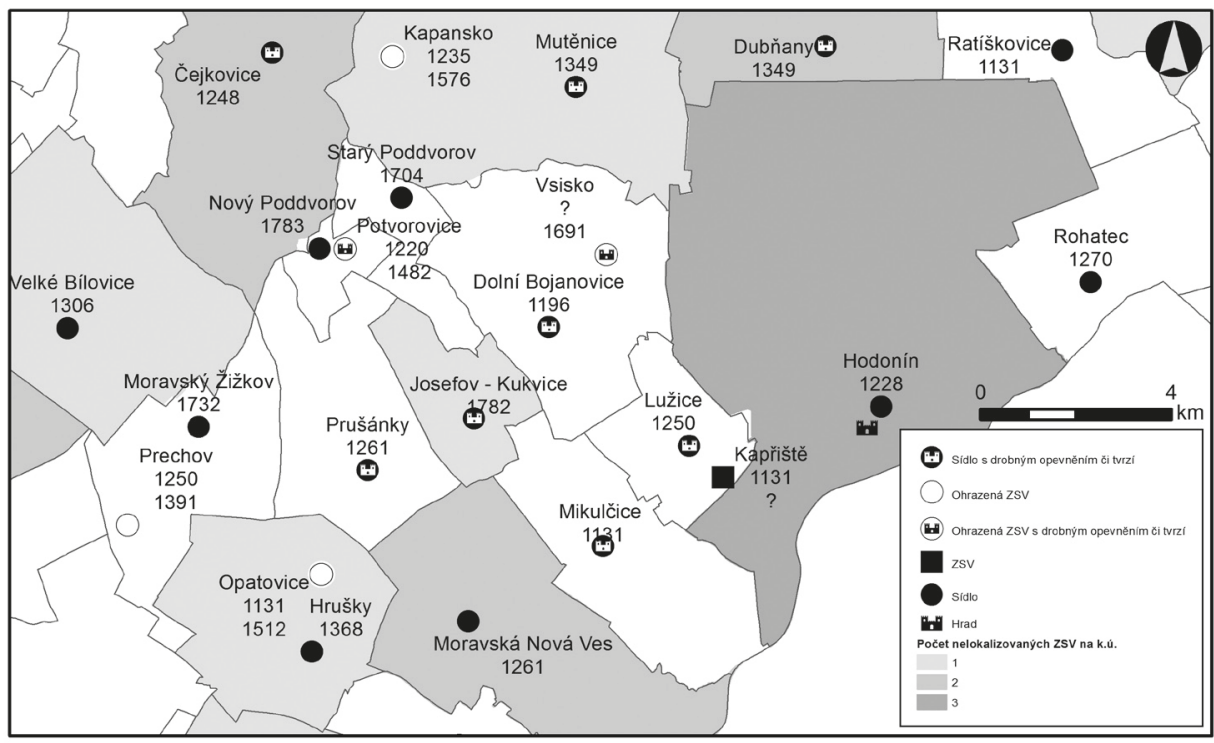

Obr. 9. Struktura osídlení v okolí ZSV „Vsisko" vyjma přesně nelokalizovaných ZSV (zdroj dat: Nekuda-Unger 1981; mapa: Petr Dresler a Michal Vágner).

Fig. 9. Settlement structure in the surroundings of DMV "Vsisko" excluding the inexactly localised DMVs (data source: Nekuda - Unger 1981; map: Petr Dresler and Michal Vágner).

anomálií na lokalitě - například menších žlabů apod. Diagonální linie jsou výsledkem dlouhodobé a stálé aktuální zemědělské činnosti na lokalitě - orby (Obr. 7).

\section{Struktura osídlení v okolí Vsiska}

Jak víme z písemných pramenů, ves „Vsisko“ je poprvé uváděna v roce 1691, a to již jako „množství let“ pustá. Díky absenci keramického materiálu z lokality ji ovšem nelze přesněji časově zařadit. Na základě prvních písemných zmínek z okolních zaniklých i nezaniklých vesnických sídel pouze rámcově domnívat, že ves fungovala někdy v rozmezí 13. až 16 . století. Na základě těchto údajů je možné rekonstruovat hypotetickou strukturu osídlení v blízkém okolí lokality, tedy to, které lokality mohly být během fungování v přímé interakci s dnes už zaniklou vesnicí a drobným opevněným sídlem.
V době trvání „Vsiska“ už zcela jistě existovaly nedaleké Dolní Bojanovice, které jsou poprvé zmíněny v roce 1196 . V letech 1412-1415 je zde zmíněna i tvrz (Esterka - Ondruš 1996). Dalším vesnickým sídlem s tvrzí jsou severně položené Mutěnice. Ty jsou poprvé zmíněny v roce 1349.

Na katastru obce Mutěnice se nachází další dvě $\mathrm{ZSV}$, z nichž pouze jednu se podařilo přesně lokalizovat. Jedná se o ZSV „Kapansko“ či „Kapanice“ (k.ú. Mutěnice), která se nachází asi 6 km severozápadně od ZSV „Vsisko“. Poprvé byla zmíněna v roce 1235 a již jako pustá je uváděna v roce 1576 (CDB III/1 150, č. 120; CDB 211, č. 131; ZDB 297, č. 135; Nekuda 1961, 97). Druhá vesnice z mutěnického katastru je ZSV „Kuničky“ (k.ú. Mutěnice), o níž máme první zmínku z roku 1286. Jako pustou vsí byly zapsány v roce 1497. Lokalita je uváděna poblíž tzv. Zbrodské myslivny. V roce 1511 byl na pozemcích pusté vsi zřízen rybník (Nekuda 1961, 60-61), a proto je možné se domnívat, že zbytky vesnice se 
dnes nachází pod hladinou nedalekého rybníka „Třetí Zbrod“.

Asi $6 \mathrm{~km}$ severovýchodním směrem se nachází město Dubňany, o kterém máme první písemnou zmínku z roku 1349. Na jejím katastru se jednak nacházela ZSV "Jarohněvice“, jednak ZSV „Mokronosy“ (obě k.ú. Dubňany). Prvně jmenovaná lokalita je poprvé uvedena $\mathrm{v}$ roce 1141 jako majetek spytihněvského kostela. V roce 1408 je zde uváděn mlýn, tvrz, kostel a dvůr, který se dochoval do dnešních dnů. Vesnice byla zničena na konci 15 . století, pravděpodobně $\mathrm{v}$ roce 1491 , a to $\mathrm{z}$ důvodu stavby Jarohněvického rybníka. V roce 1492 je již uváděna jako pustá (Nekuda 1961, 78-79). Druhá vesnice se nacházela severozápadně od Dubňan. ZSV "Mokronosy“ je poprvé zmíněna v roce 1349 (ZDO 3, č. 65). V roce 1408 je zde zmíněn kostel, rybník dvůr a tvrz (ZDO 279, 284, č. 641, 716). Jako pustá je zmiňována v roce 1492 (Nekuda 1961, 65; Nekuda - Unger 1981, 197)

Několik kilometrů západně od ZSV "Vsisko" se nacházela další vesnice, a to již dnes zaniklé „Potvorovice“ (k.ú. Nový Poddvorov). Ty jsou v písemných pramenech poprvé zmíněny v roce 1220 (CDB II 180, 322, č. 195, 321). Jako pusté se uvádějí po česko-uherských válkách v roce 1482 (Hurt 1934, 104, 125).

Jižně od ZSV „Vsisko“ zcela jistě existovala v době jejího trvání obec Lužice, která je poprvé zmíněna $\mathrm{v}$ roce 1250 jako součást majetku kláštera velehradského. Několik kilometrů jihozápadním směrem od „Vsiska“ dnes najdeme obec Josefov. Ta byla v roce 1782 nově založena na území bývalého panského dvora, postaveného na místě zaniklé vesnice zvané „Kukvice“ (k.ú. Josefov). Ta se uvádí jako ves po celé 16. století a v roce 1607 je zde zmíněna i tvrz. V urbárí panství hodonínského je k roku 1691 uvedeno, že dědina „Kukvice“ je v ten čas již pustá (Nekuda 1961, 145).

\section{Diskuze}

Ačkoliv se geofyzikální prospekcí podařilo doložit zbytky př́kopu pouze na západní a jihozápadní straně lokality, tak je velice pravděpodobné, že vesnice byla ohrazena ze všech stran. Tomu by nasvědčovaly jak analogie $\mathrm{z}$ dalších zaniklých vesnic, např́íklad ze ZSV „Opatovice“ (k.ú. Hrušky u Břeclavi), kde se taktéž podařilo geofyzikálním průzkumem doložit zbytky ohrazení v podobě př́íkopu (Dresler - Tencer - Vágner 2015a), tak i informace získané studiem historických mapových archiválií. Na II. vojenském mapování a císařských povinných otiscích stabilního katastru je trat „Wsiszko“ zřetelně vymezena vůči okolním parcelám. Toto vymezení nejenže jasně koresponduje s průběhem ohraničení, doloženým nedestruktivními metodami na západní a jižní straně lokality, ale dává tušit i průběh ohrazení na straně východní a severní. Na jižní straně se navíc podařilo geomagnetickou prospekcí odhalit i možný vstup do ohrazeného areálu. Zde byl zachycen dvojitý př́kop, který je zhruba uprostřed svého průběhu na několik metrů přerušen.

Geofyzikální průzkum dále odhalil velké množství anomálií uvnitř ohrazeného areálu, které lze interpretovat jako pozůstatky běžných zahloubených sídlištních objektů. Zachycené objekty se koncentrují okolo lineární anomálie, která se táhne středem delší osy vesnice. Pravděpodobně se jedná o starší fázi historické komunikace, která vedla středem vesnice v době jejího trvání. Navíc se zdá, že cesta vede směrem $\mathrm{k}$ domnělému vstupu do ohrazeného areálu vsi, který se podařilo zachytit geofyzikální prospekcí v jižní části lokality. Průběh nově objevené komunikace navíc částečně koreluje i s cestou zaznamenanou na pozděǰsích historických mapách, která je zde zaznamenána pár desítek metrů východně (Obr. 2, 3). 


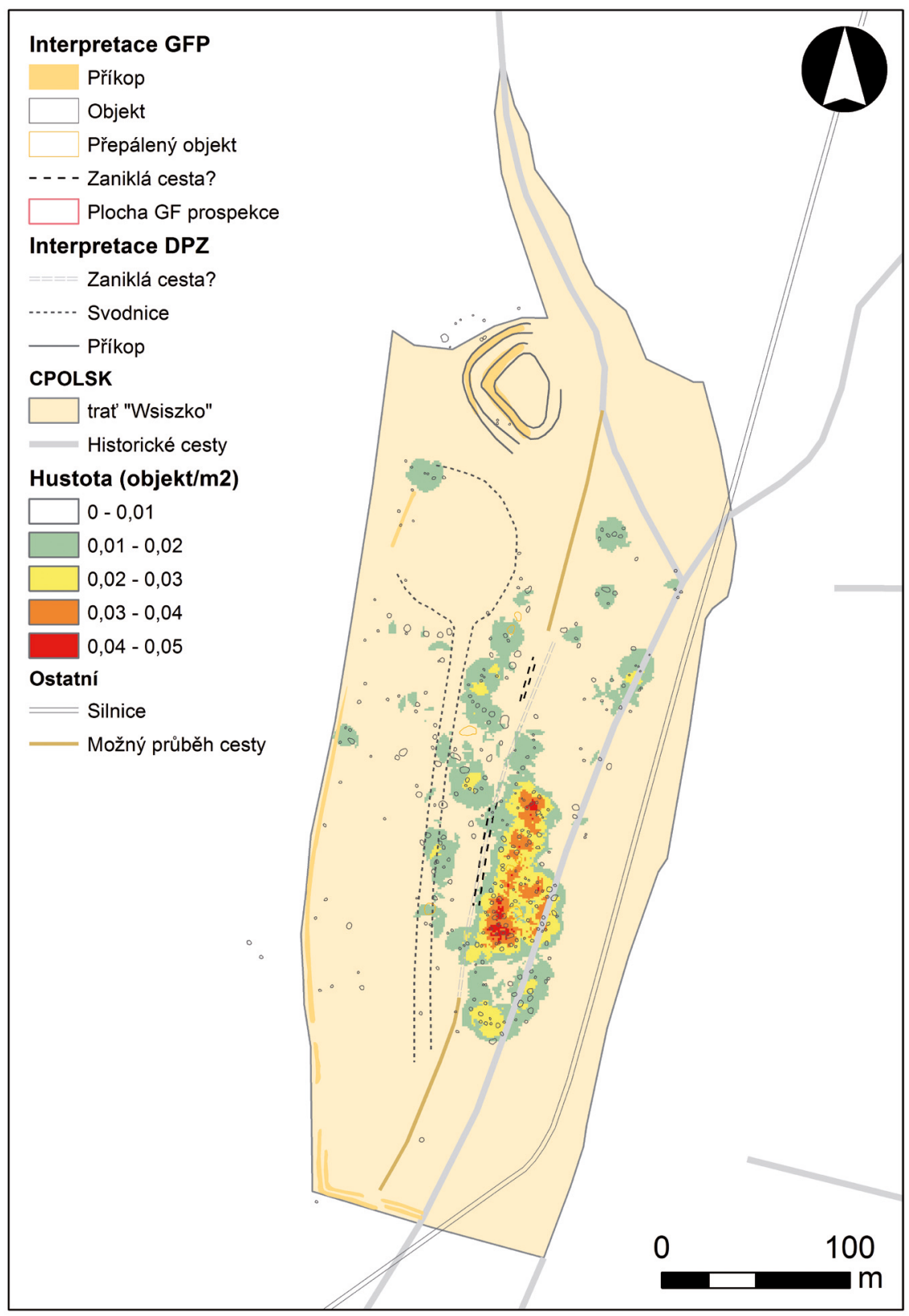

Obr. 10. Shrnutí výsledků nedestruktivní prospekce na ZSV „Vsisko". Jako vstupní data pro podkladový rastr intenzity osídlení posloužily za pomoci geofyzikální prospekce interpretované sídlištní a přepálené objekty v podobě polygonů, které byly převedeny nástrojem „Feature fo Point" (ArcMap 10.3.) na body. Nástrojem „Point density" byl následně vypočítán rastr intenzity bodových prvků. Ten představuje hustotu sousedních bodů kolem každé rastrové buňky v okruhu 10 m od každého jednotlivého bodu; autor: Michal Vágner).

Fig. 10. Summary of results of non-destructive survey in the DMV "Vsisko" (background raster of settlement intensity was created on the basis of data from magnetometric survey with the help of "Density" tool in ArcMap 10.3; author: Michal Vágner). 
Větší část identifikovaných sídlištních objektů se nachází na východní straně od zachycené cesty, a proto lze předpokládat, že se zde koncentrovala i hlavní část osídlení vesnice (Obr. 10). $\mathrm{Na}$ druhé straně cesty je distribuce sídlištních objektů poněkud odlišná, ale i tak se lze domnívat, že se zde mohly nacházet obytné stavby. Po obou stranách cesty se podařily magnetometrickou prospekcí zachytit i výrazně přepálené objekty, které by mohly indikovat přítomnost pyrotechnických zařízení, at' už otopného či výrobního charakteru (Obr. 7, 8).

Na základě těchto informací lze vytvořit i hypotetickou půdorysnou rekonstrukci zaniklé vsi. Ohrazený areál zaujímal plochu o výměře cca 7 až 8,5 ha. Vesnici obklopoval minimálně ze dvou stran příkop, který byl minimálně na jižní straně zdvojený. V těchto místech se nacházel i pravděpodobný vstup do ohrazeného areálu. Severojižní osou vesnice vedla cesta. Okolo ní se nacházela jednotlivá obydlí. Podle dosavadních informací se však zdá, že větší část sídelních aktivit se odehrávala na východní straně od cesty. Severně od vesnice se nacházelo drobné opevněné sídlo s vazbou na vesnické osídlení, které bylo obehnáno dvojitým příkopem. Je možné, že vnější př́ikop opevněného sídla byl součástí ohrazení samotné vesnice a tyto dvě komponenty tvořily jeden uzavřený komplex. Eventuálně je možné, že se v místech styku ohrazení vesnice $s$ vnějším př́kopem opevněného sídla nacházel jakýsi vstupní koridor ve směru SZ-JV do celého areálu.

$\mathrm{O}$ tom, kdy přesně vesnice fungovala a jak zanikla lze jen spekulovat. Rámcově ji lze datovat do období mezi 13. až 16. stoletím. Důvodem zániku mohou být válečné události či nevhodná lokalizace díky poměrně velké vzdálenosti od nejbližšího zdroje vody. Ten se nachází v podobě řeky Kyjovky asi 1,2 km výhodně od lokality. Druhý zdroj vody, potok Prušánka, která protéká nedalekými Dolními Bojanovicemi, se nachází asi 1,5 km jižním směrem.

\section{Závěr}

Kombinací studia snímků dálkového průzkumu Země, analýzy historických mapových archiválií a výsledků plošné geomagnetické prospekce se podařilo na zaniklé vesnici „Vsisko“ zachytit jednak zbytky jejího vnějšího ohrazení v podobě př́kopu, zaniklou cestu, která vesnicí procházela jako severojižní osa, ale i náznaky vnitřní zástavby, která se koncentrovala okolo této zachycené komunikace. Další informace o lokalitě by mohl přinést jednak povrchový průzkum, který by dopomohl k přesnějšímu časovému zařazení zaniklé vesnice a drobného opevněného sídla, popřípadě regulérní archeologický výzkum, který by se cíleně opíral o výsledky získané geofyzikální prospekcí. Ten by mohl přinést i přesnější odpovědi týkající se samotné konstrukce jednotlivých domů, poprrípadě celých usedlostí ve vesnici. Na základě výsledků geofyzikální prospekce se prozatím zdá, že na lokalitě nebylo ve větší míře využito ke stavbě domů kamene. Nepřímo lze tak soudit, že domy musely být stavěny jinou stavební technikou. Nabízí se dřevo, hlína, nebo kombinace obojího. 


\section{Prameny a literatura}

CDB: Codex diplomaticus et epistolaris regni Bohemiae I-VI, 805-1283, (Friedrich G.-Kristen, Z.-Šebánek, J.-Dušková, S.-Sviták, Z.-Krmíčková, H.-Krejčíková, J.-Nechutová J., edd.). Praha 1904-2006.

CDM: Codex diplomaticus et epistolaris Moraviae VIXII, 1307-1399, (Chytil, J.-Brandl, V., edd.). Brno 1854-1890.

ZDO: Moravské zemské desky (Die Landtafel des Markgrafthumes Mähren). I. sv. řady olomoucké 1348-1466, (Chlumecký, P.-Chytil, J.-Demuth, K.-Wolfskron, A., edd.). Brno 1856.

Bálek, M. 1997: Výsledky leteckého snímkování na Moravě, Přehled výzkumů 38, 307-311.

Bálek, M. - Unger, J. 1996a: Ohrazené středověké vesnice na jižní Moravě, Archaeologia Historica 21, 429-442.

Bálek, M. - Unger, J. 1996b: Umgrenzte mittelalterliche Dörfer in Südmähren. In: Ruralia I, Památky archeologické - Supplementum 5, 296-300

Červinka, I.L. (1931). Pusté vsi.Nepublikovaná manuscript.

Čižmářová, J. 1993: Zjištovací výzkum v Dolních Bojanovicích (okr. Hodonín), Přehled výzkumů 34, 116-117.

Dresler, P. - Tencer, T. 2016: Neznámé opevněné sídlo v Dolních Bojanovicích, Archaeologia Historica 41, 241-249.

Dresler, P. - Tencer, T. - Vágner, M. 2015a: Objev kostela na zaniklé středověké vsi Opatovice (k.ú. Hrušky) a její struktura, Jižní Morava 51, 399-407.

Dresler, P. - Tencer, T. - Vágner, M. 2015b: Prospekce zaniklé středověké vesnice Opatovice, k.ú. Hrušky, Studia Archaeologica Brunensia E20, 113-132.

Esterka, F. - Ondruš, V. 1996: Dolní Bojanovice. Publikace k 800. výročí první písemné zprávy o trvání obce Dolní Bojanovice. Dolní Bojanovice.

Hladik, M. - Milo, P. - Tencer, T. - Zeman, J. 2013: Geofyzikálny prieskum sídliskových štruktúr v Moravskej Novej Vsi, okr. Břeclav. In: Chvojka, O. (Ed.), ARCHEOLOGICKÉ PROSPEKCE A NEDESTRUKTIVNÍ ARCHEOLOGIE v Jihočeském kraji, kraji Vysočina, Jihomoravském kraji a v Dolním Rakousku. Sborník z konference, Jindřichův Hradec 6. 3. - 7. 3. 2013, 131-136
Hurt, R. 1934: Dějiny cisterciáckého kláštera na Velehradě I. 1205-1650. Olomouc.

Jan, L. - Štěpánek, V. (Eds.). 2002: Mutěnice: dějiny vinařské obce. Mutěnice.

Kordiovský, E. 1977: Sídlištní hustota ve středověku na Kloboucku (okres Břeclav), Archaeologia Historica 2, 261-266.

Kordiouský, E. 1980: Příspěvek k metodice povrchového průzkumu zaniklých středověkých osad na brněnském Kloboucku, Archaeologia Historica 5, 183-186.

Křivánek, R. 2004: Geofyzikální metody. In: Kuna, M. (Ed.), Nedestruktivní archeologie: teorie, metody a cíle. Non-destructive archaeology: theory, methods and goals, 117-183, Praha.

Milo, P. 2009: Geofyzikálny prieskum včasnostredovekých sídlisk - prínos pre archeológiu alebo strata času? In: Dresler, P. - Měřínský, Z. (Eds.), Archeologie doby hradištní, 38-53, Brno.

Milo, P. 2013: Geofyzikálne prieskumy včasnostredovekých sídliskových lokalít na dolnom Podyjí, Archeologické rozhledy LXV, 706-734.

Milo, P. 2014: Frühmittelalterliche Siedlungen in Mitteleuropa. Eine vergleichende Strukturanalyse durch Archäologie und Geophysik. Bonn.

Nekuda, V. 1961: Zaniklé osady na Moravě v období feudalismu. Brno.

Nekuda, V. - Unger, J. 1981: Hrádky a tvrze na Moravě. Brno.

Unger, J. 1974: K lokalizaci některých zaniklých středověkých osad v okolí Pohořelic (okres Břeclav), Jižní Morava 10, 22-33.

Unger, J. 1975: K lokalizaci některých zaniklých středověkých osad v okolí Pohořelic (okres Břeclav), Zprávy Československé společnosti archeologické při Čs. akademii věd XVII, 58-60.

Unger, J. 1982: Vývoj osídlení na soutoku Jihlavy a Svratky ve 13. až 15. století, Archaeologia Historica $7,169-177$.

Unger, J. 1987: Výzkum opevněného sídla typu 'motte' na zaniklé vsi Divice u Brumovic (okr. Břeclav), Přehled výzkumů 30, 49-51.

Unger, J. 1988: Motte a kostel v zaniklé vsi Divice u Brumovic, okr. Břeclav, Archaeologia Historica 13, 369-374.

Vágner, M. - Škvrňák, J. - Dresler, P. v tisku: Nové poznatky $\mathrm{k}$ ohrazeným vesnicím na jižní Moravě z pohledu dálkového průzkumu Země. 


\section{Deserted medieval village "Vsisko" from the perspective of non-destructive survey methods}

The study of remote sensing images and analysis of historical archival maps helped to identify the deserted medieval village "Vsisko" with adjacent small fortified residence in the northern part of cadastral district of Dolní Bojanovice village. On grounds of these findings, both sites were examined by geophysical survey using a magnetometer. In the place of a small fortified residence, a part of a double ditch was identified, whose external course enclosed an ir- regularly trapezoidal area sized $28 \times 33 \mathrm{~m}$. The survey in the area of the deserted village captured remnants of its external enclosure in the form of a ditch and potential entrances into the enclosed area. It also identified a defunct road, which passed through the village in north-southern direction, and indications of internal build-up which was concentrated around the identified road.

\section{Mgr. Michal Vágner}

- Ústav archeologie a muzeologie, Filozofická fakulta, Masarykova univerzita, A. Nováka 1, 60200 Brno, Česká republika vagnermichal@mail.muni.cz

\section{Mgr. Tomáš Tencer}

- Ústav archeologie a muzeologie, Filozofická fakulta, Masarykova univerzita, A. Nováka 1, 60200 Brno, Česká republika tomastencer@phil.muni.cz

\section{Mgr. Petr Dresler, Ph.D.}

- Ústav archeologie a muzeologie, Filozofická fakulta, Masarykova univerzita, A. Nováka 1, 60200 Brno, Česká republika dresler@phil.muni.cz

\section{Mgr. Michaela Prištáková}

- Ústav archeologie a muzeologie, Filozofická fakulta, Masarykova univerzita, A. Nováka 1, 60200 Brno, Česká republika pristakova@mail.muni.cz

\section{Bc. Jakub Šimík}

- Ústav archeologie a muzeologie, Filozofická fakulta, Masarykova univerzita, A. Nováka 1, 60200 Brno, Česká republika shemik@mail.muni.cz 